\title{
Kernos
}

Revue internationale et pluridisciplinaire de religion

grecque antique

32 | 2019

Varia

\section{Orpheus in Aeschylus and the Thracian child-eater on a hydria from the British Museum}

\section{Bartek Bednarek}

\section{(2) OpenEdition}

\section{Journals}

Electronic version

URL: https://journals.openedition.org/kernos/3098

DOI: 10.4000/kernos.3098

ISSN: 2034-7871

\section{Publisher}

Centre international d'étude de la religion grecque antique

\section{Printed version}

Date of publication: 1 December 2019

Number of pages: 13-27

ISBN: 978-2-87562-229-7

ISSN: 0776-3824

\section{Electronic reference}

Bartek Bednarek, "Orpheus in Aeschylus and the Thracian child-eater on a hydria from the British Museum", Kernos [Online], 32 | 2019, Online since 01 October 2021, connection on 01 February 2022. URL: http://journals.openedition.org/kernos/3098 ; DOl: https://doi.org/10.4000/kernos.3098

This text was automatically generated on 1 February 2022

Kernos 


\title{
Orpheus in Aeschylus and the Thracian child-eater on a hydria from the British Museum
}

\author{
Bartek Bednarek
}

I would like to thank Ioanna Patera and the anonymous referees for their priceless suggestions that improved this paper. The research was possible thanks to the financial support of the National Science Centre in Poland (grant no. 2016/20/S/HS3/00062) and de Brzezie Lanckoronski Foundation.

To the memory of Dzieciojad (Child-eater), a monster that lived in my closet when I was a child.

1 An Attic red-figure hydria now in London, most likely dating slightly before $450 \mathrm{BCE},{ }^{1}$ is decorated with a disturbing scene (Fig. 1) that has been thus far interpreted in two alternative ways, both of which, as I intend to argue, are wrong. It shows a man in a Thracian outfit, who, while facing the viewer, ${ }^{2}$ holds on his left arm a dead child. With his right hand, he lifts to his mouth a limb he has clearly torn from its body. To the viewer's left from the cannibal, Dionysus is standing with a thyrsus and is making a gesture with one hand. To the right from the cannibal, another man in Thracian dress is running away from the scene.

2 In his article published in 1890, C. Smith observed that "the episode of a child torn to pieces and devoured occurs very rarely in Greek mythology". ${ }^{3}$ The feast of Thyestes and that of Tantalus are among the few exceptions, but given that Dionysus played no role in these stories, the only possible interpretation of the scene, as Smith concludes, must be that it shows Zagreus being killed and eaten by Titans. ${ }^{4}$ Given that this story was thought of as "Orphic" and "Orphic doctrine" was believed to have originated in Thrace, this would account for the Thracian garments of the Titans. Back in 1890 this might have seemed very logical; today, given the whole effort that generations of scholars from Wilamowitz to Edmonds made in order to deconstruct the notion of "Orphism" as a doctrine, questioning, among others, the role of the Zagreus myth, ${ }^{5}$ such an interpretation seems much less plausible, though not completely impossible 
per se. However, as Topper observed, ${ }^{6}$ what makes it unlikely is the gesture of Dionysus, who does not seem to be displeased or scared (as the Thracian on the right is); certainly he does not try to prevent the act of cannibalism. ${ }^{7}$ This strongly suggests that the child being devoured by the Thracian is not an alter-ego of Dionysus, which makes an alternative interpretation much more plausible. According to Topper, ${ }^{8}$ the central figure on the vase must be Lycurgus, the king of the Thracian Edonians, shown at the moment when he eats his son Dryas.

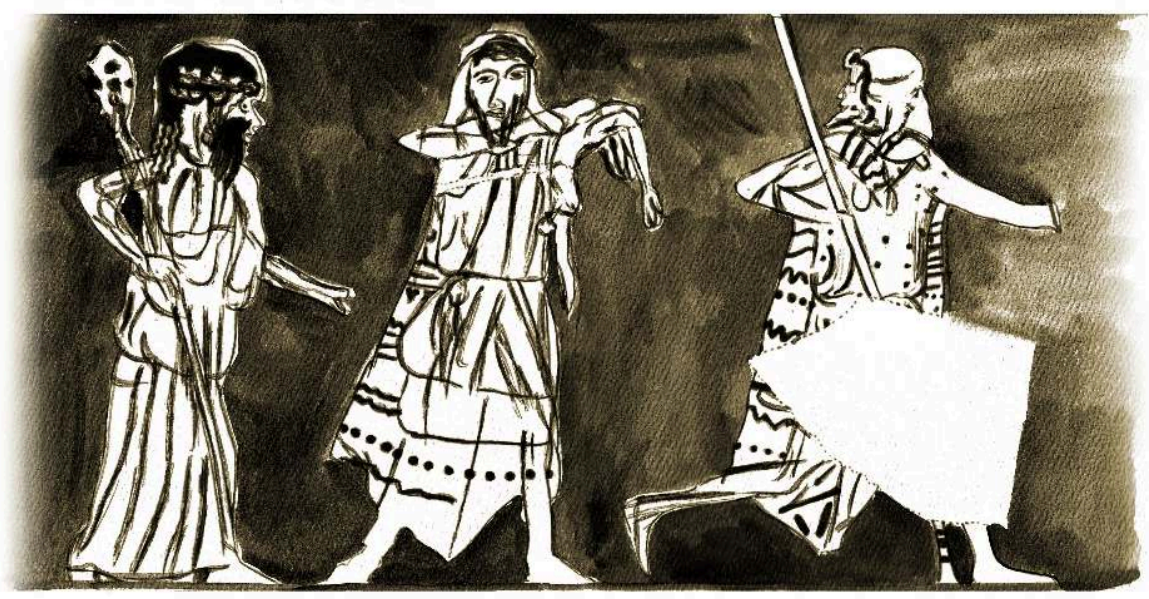

Fig. 1a. Attic red-figure hydria. London, British Museum E 246. BAD 9981.

DRAWING BY ADAM CHMIELEWSKI

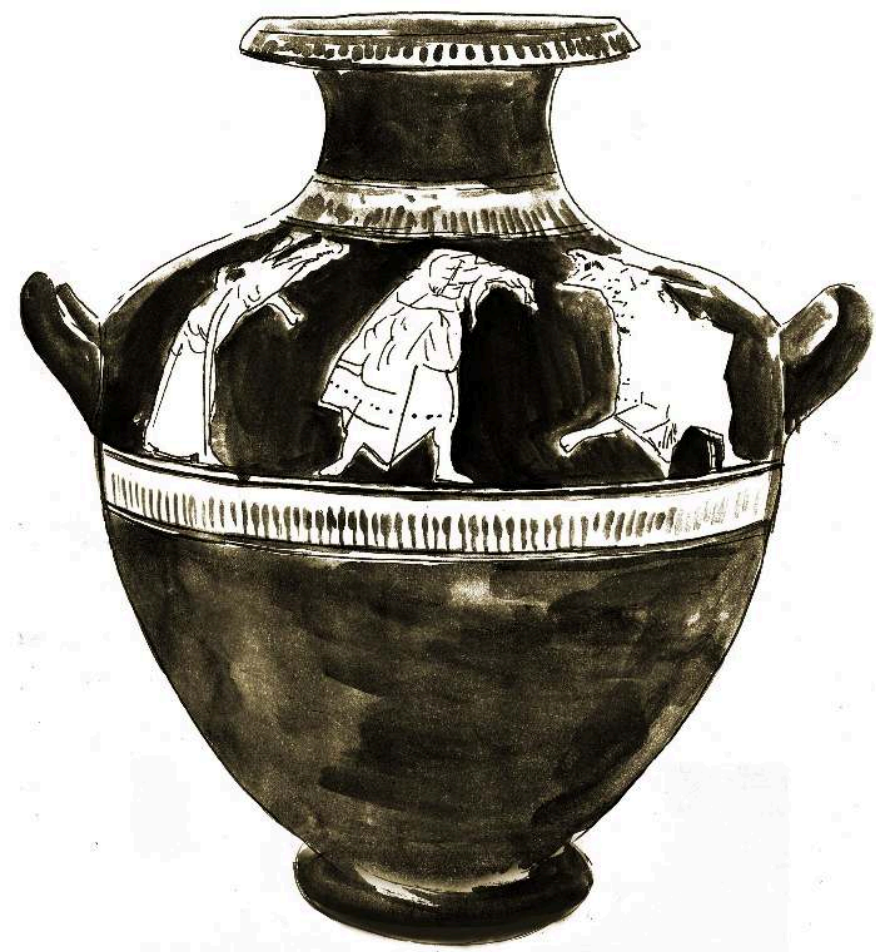

Fig. 1b. Attic red-figure hydria. London, British Museum E 246. BAD 9981. DRAWINg BY ADAM CHMIELEWSKI. 


\section{Lycurgus}

3 Lycurgus was known already to the author of the sixth book of the Iliad, where he features as an enemy of Dionysus. ${ }^{9}$ His story was subsequently dramatized by a certain Polyphrasmon in $467^{10}$ and, probably a few years later, by Aeschylus, whose tetralogy Lycurgeia is known to have been very successful among the Athenian audience. ${ }^{11}$ Although extant fragments of the plays do not mention this, it is reasonable to believe that one of the most memorable moments in the story was that in which Lycurgus, convinced that he was cutting the newly introduced vine, killed his own son, Dryas. Such a reconstruction results from comparison between a summary of the story in ps.Apollodorus ${ }^{12}$ and three Attic vases from the fifth century (as well as some later SouthItalian representations). The most explicit seems to be a red-figure hydria from Kraków dated to the mid-fifth century (Fig. 2). ${ }^{13}$ It shows Lycurgus ready to strike the youth perched on an altar and extending his hands towards his father, who cannot see him because of a vine-branch, which Dionysus holds in front of his eyes.

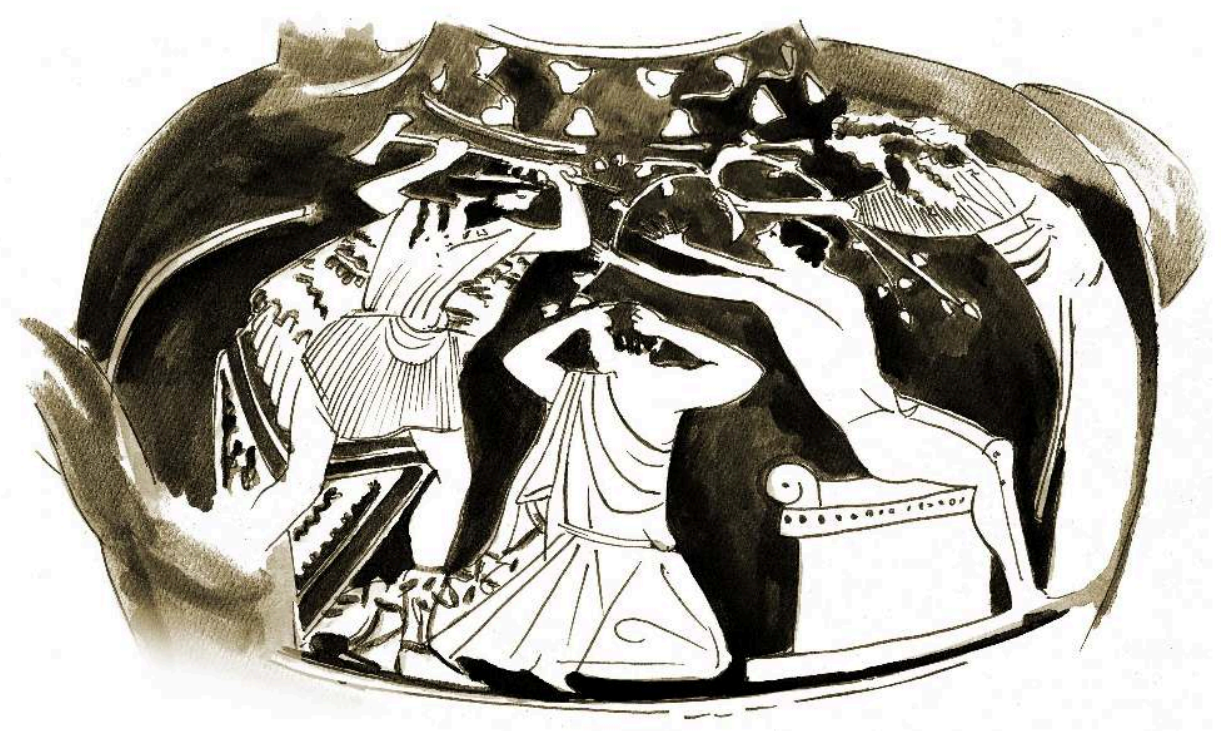

Fig. 2. Attic red-figure hydria. Kraków, National Museum 1225. BAD 214835.

DRAWINg BY ADAM CHMIELEWSKI.

4 The sacrificial connotations of this and related scenes, ${ }^{14}$ as Topper contends, suggest that Lycurgus is not only about to kill Dryas, but is also very likely to go further in violating the rules of sacrifice. Instead of an animal he will eat his son, as is supposedly shown on the London hydria under discussion. This would be very plausible if not for the fact that the failed ritual shown on the hydria from Kraków is that of supplication rather than sacrifice. ${ }^{15}$

This results from the fact that the youth, unlike a sacrificial animal, is sitting on the altar rather than standing next to it or being lifted above it. His sitting posture with hands outstretched towards the person to whom he is supplicating is part of a traditional repertoire of gestures that characterizes suppliants in Greek poetry from Homer on ${ }^{16}$ and is very common in vase painting, where, it seems more often than not, the suppliant is sitting on an altar. ${ }^{17}$ 
Obviously, it would be a mistake to contend that supplication has absolutely nothing in common with sacrifice, given that it often takes place in a sacred space. Such a choice seems to result from the inner logic of supplication, based on something one may call blackmail. If the supplication fails, and especially when the suppliant's blood stains an altar, it causes a pollution, which almost inevitably interferes with the efficiency of the rituals performed on the altar. Thus, the killing of a person on an altar violates a sacrificial $\operatorname{code}^{18}$ perhaps in a way parallel to that in which killing a suppliant clinging to a cult statue ${ }^{19}$ or temple door ${ }^{20}$ puts at serious risk the future communication between the killer and the divinity in question. ${ }^{21}$

However, violation of the altar space does not necessarily entail violation of alimentary taboos. ${ }^{22}$ Usually, it does not, given that very few, if any, cases of failed supplication we know of seem to evoke an act of cannibalism. For example, the scene with Clytemnestra killing Cassandra next to an altar (the weapon, a double axe, also used by Lycurgus may further enhance associations with sacrifice) shown in the tondo of an Attic cup in Ferrara $^{23}$ is hardly meant to suggest that Cassandra was subsequently eaten. Similarly, Medea, who is frequently depicted as killing her sons on or next to an altar, ${ }^{24}$ is never reported to have committed an act of cannibalism.

These two examples also seem to be pertinent because just as - supposedly - the representation on the hydria from London, the scenes with Clytemnestra and Medea are likely to have been influenced by tragedy, a genre in which a perverted sacrifice provides an extremely rich source domain of metaphors for illicit killing, especially within one's family. ${ }^{25}$ Yet, as Seaford observes, tragedy, unlike epic, explores the killphase of the ritual rather than communal feasting that often ensued in a real-life thysia. ${ }^{26}$ Thus, when proper human sacrifice is referred to, it excludes eating, as in the case of the sphagion of Polyxena or the adaitos thysia of Iphigenia. ${ }^{27}$ When an act of murder is figuratively spoken of as a sacrifice, eating is not mentioned apart from on very rare occasions, such as the feast of Thyestes. ${ }^{28}$ In this exceptional case, an act of killing for cannibalistic purposes is described in terms that may be evocative of sacrifice. However, it would be highly misleading to claim that the cannibalistic reference results here from the sacrificial connotations of the terms in which the killing is described. Thus, the exception confirms the rule; an act of cannibalism is not what we should expect after the sacrificial killing of a human. ${ }^{29}$

Returning to Lycurgus, Topper may be right in that by killing a suppliant at an altar ${ }^{30}$ with a sacrificial axe, Lycurgus de facto did what a sacrificer would do with an animal. It is also likely that it was described in such a way by Aeschylus (for example, in a messenger's speech). Thus, Lycurgus' deed could be figuratively assimilated to that of a sacrificial killing. Yet, as previously mentioned, eating does not automatically follow killing. At least in tragedy, it almost never does. Thus, even if we admit that Dryas might have been accidentally killed in a sacrificial manner, it does not follow that he was also accidentally eaten by Lycurgus, who, as far as we can tell, was convinced that he was cutting non-edible plants rather than performing a sacrifice.

Therefore, the link between the cannibal on the London hydria and Lycurgus is wanting, unless one accepts a less direct connection, which I intend to suggest. 


\section{Arabian shepherds}

Somewhat surprisingly, within a lengthy narration about Lycurgus' resistance against Dionysus, ${ }^{31}$ Nonnus recites one of the few stories about cannibalism that are known from Greek literature. It begins, slightly unexpectedly, after a lacuna: ${ }^{32}$

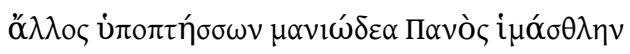

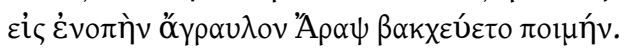

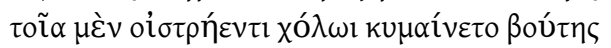

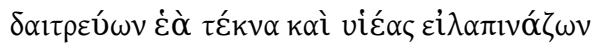

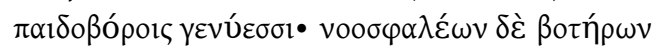

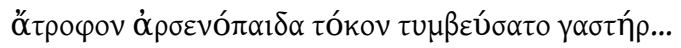

Another Arabian shepherd, crouching under Pan's whip of frenzy, went on a maddened battle among the fields. Also an oxherd, driven mad by rage, seethed and cut up his own children, feasting on his sons with child-devouring jaws. Stomachs of deranged herdsmen became graves of their ill-fed male offspring... ${ }^{33}$

The passage breaks off with another lacuna, after which the focus shifts towards Lycurgus and his punishment. Thus, we never learn how the frenzy of Arabian shepherds ended. However, given that the subject-matter is not addressed again in the text, it is reasonable to infer that the end of the crisis was described in its missing part. Why is this relevant? First of all, because Nonnus, who speaks of Arabians here, has transferred the whole episode of Lycurgus from Thrace to Arabia; thus, if he follows an earlier version of the story, it is very likely to have featured Thracian rather than Arabian cannibals. These would be the only Thracian cannibals we hear of. As such, they would match the London hydria much better than Titans or Lycurgus. The question that remains is whether this story attested as late as in Nonnus can be retrojected to the period in which the vase in question was created. No direct evidence is available.

\section{Orpheus as a culture hero}

There is, however, a widely discussed passage in Aristophanes' Frogs in which the spirit of Aeschylus speaks of merits of a number of famous past poets, beginning with Orpheus: ${ }^{34}$

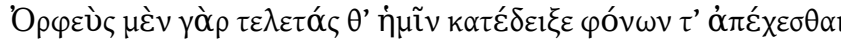

Orpheus taught us the rites ${ }^{35}$ and to abstain from bloodshed.

This line has long puzzled scholars. Its most obvious interpretation relates it to the alleged vegetarianism of Orpheus and his followers. ${ }^{36}$ It has been recognised, however, that such a statement made on a comic stage in the context of a civic festival, which included a hecatomb, could hardly be understood as a reference to the benefits of abstinence from meat and killing animals. ${ }^{37}$ Alternatively, as Graf argued, ${ }^{38}$ Aristophanes might have had in mind the role of Orpheus as a cultural hero, who taught primitive human beings to abstain from primordial allelophagy and to adopt more civilised way of nourishment in a form of either animal meat or cereals. This agrees with some of the views held by intellectuals from Prodicus to Porphyry and beyond, who thought that in earlier stages of cultural development people ate other people, possibly including their own offspring, until some inventors taught them agriculture and husbandry. This seems to be alluded to by Themistius, ${ }^{39}$ who states that divine worship would be impossible without agriculture, because gods are honoured 
with its products given to them as offerings and sacrifices. Subsequently, he mentions Prodicus, likely in order to substantiate the claim that the very notion ${ }^{40}$ of divinity comes from agriculture. He then continues: ${ }^{41}$

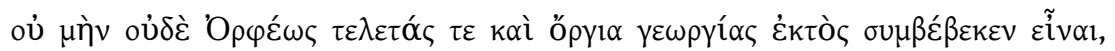

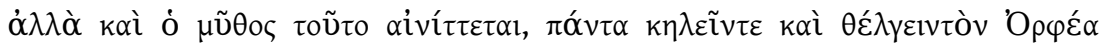

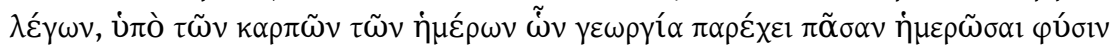

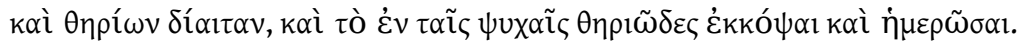

Even the Orphic ceremonies and rites did not exist without agriculture, to which also the myth alludes by saying that Orpheus bewitched and enchanted everything and he domesticated the nature and the behaviour of wild beasts as well as he eradicated and harnessed what is beastly in souls by means of the cultivated fruits that the agriculture provides.

The origins of this rationalised version of the story of Orpheus are unknown. It would be tempting to think that it previously appeared in Prodicus, but Themistius is not explicit in attributing this part of the material to the sophist. Because it does not find parallels in other passages on Prodicus' thought, it is not included in editions of his fragments and testimonies. ${ }^{42}$ However, whatever its origin, it clearly presupposes the existence of a myth in which Orpheus is linked not only to the music and divine cult, but also to the development or propagation of agriculture. A similar view is also expressed by Horace in the Ars poetica: ${ }^{43}$

\author{
Siluerstes homines sacer interpresque deorum \\ caedibus et uictu foedo deterruit Orpheus, \\ dictus ob hoc lenire tigris rabidosque leones \\ The holy prophet of gods, Orpheus, deterred savage people from bloodshed and \\ disgraceful food, for this reason is said to placate tigers and furious lions
}

This passage may serve as a link between Themistius and Aristophanes, as it clearly attests to an existence of a rationalised version of the story (taming animals as a figure of speech). ${ }^{44}$ At the same time, it emphasises the dietary aspect of the innovation introduced by Orpheus among savage people..$^{45}$

\title{
Orpheus in Aeschylus
}

How is the role of Orpheus as a culture hero related to the London hydria and the passage in Nonnus? According to ps.-Eratosthenes' Catasterism 24, Aeschylus told a story of Orpheus' death at the hand of the Bassarids, Thracian women maddened by Dionysus, in one of his tragedies. In spite of the various controversies that surround this testimony, ${ }^{46}$ all scholars agree that it means that the tragedy in question was a part of the Lycurgeia. It has also been argued in a convincing manner that the story was unlikely to have been treated marginally as a short digression. ${ }^{47}$ Rather, it was central for the plot of one of the tragedies. ${ }^{48}$ Thus, the myth of Orpheus was clearly thought of as a part of the tale in which Dionysus introduces viticulture to the country of Lycurgus. ${ }^{49}$

Did Aeschylus describe Orpheus as a culture hero who teaches people agriculture? Certainly not in the exact way in which later intellectuals imagined inventors of new skills who convert "primitive" people to civilisation..$^{50}$ Instead, there are good reasons to suspect that Lycurgeia featured a temporary crisis in which already "civilised" people (even if they were "barbarians") returned to savagery under the influence of one divinity or another. Such a kind of reversal, triggered by the advent of Dionysus, is 
described in the Bacchae of Euripides ${ }^{51}$ More importantly, this is what seems to be addressed in the passage in Nonnus quoted above, in which the resistance of Lycurgus against Dionysus causes a cannibalism epidemic among his subjects. In the missing part of the text, someone, possibly Orpheus, could dissuade people from this by use of some of the resources available to him. Therapeutic music and rituals traditionally associated with Orpheus are certainly among the possible means. This, however, does not exclude the agricultural context, which is, quite aptly, also present in the ps.-Apollodorus' summary of the Lycurgus story, where it is said that when Lycurgus killed his son, the

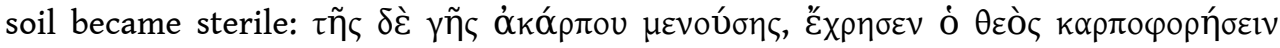

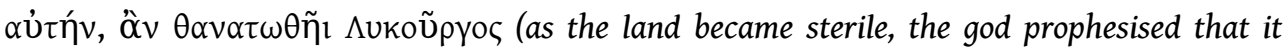
would become fertile again once/if Lycurgus is put to death).

\section{Reconstruction}

19 The material gathered above allows for the following, admittedly tentative, reconstruction:

1. Aeschylus' Lycurgeia featured the resistance of Lycurgus against Dionysus who has just arrived in Thrace. In a state of a god-sent frenzy, Lycurgus killed his son. Subsequently, and possibly as a result of it, the land stopped yielding crops [thus far, there is nothing new in this reconstruction] and maddened people turned to cannibalism. According to ps.-Apollodorus, the death of Lycurgus restored the natural order (perhaps by means of a purification). Orpheus helped restore the social order by converting people back to "civilised" food (with all likelihood, the death of Orpheus was not directly related to these events). ${ }^{52}$

2. The hydria from London alludes to the part of the story in which Thracians ate their own children and killed each other for cannibalistic purposes. This explains why one of the Thracians runs away from the other. All of this happened under the influence of Dionysus.

3. Aristophanes alluded to this episode in his Frogs, aptly putting the words in Aeschylus' mouth. However, the version that Aristophanes had in mind could have been already influenced by rationalisation (which may or may not have been due to Prodicus). In such a context, the myth (a story supposed to have happened in a particular time and place) would be taken as a reflection of the development of all humanity from early "primitivism" towards "civilisation". Orpheus is described by Aristophanes as a culture hero.

4. Horace and Themistius briefly address the rationalised version of the story.

5. Nonnus transfers the events to Arabia. He also expands the role of other divinities from the Bacchic thiasos. Thus, the frenzy is sent on Arabian shepherds by Pan. Apart from this, the episode, also in its lost part, might have to a substantial degree followed the Aeschylean model. Thus, there remained a place for Orpheus (or, possibly, some substitute thereof), who dealt with the crisis.

The reconstruction of the mythical tradition I propose above gives a new meaning to the disturbing representation on the hydria in the British Museum. What it does not explain is another unusual feature of the vessel. The picture on this rather fine piece of pottery is unparalleled in its ugliness and clumsiness. Was it made by an amateur? Or did the artist intentionally distort the figures in order to communicate something beyond our understanding? Perhaps it was simply meant to be funny? At any rate, the 
vessel had a long journey from Attica to Rhodes, where it was found by archaeologists outside a tomb at Camiros. ${ }^{53}$ Apparently, in spite of its strangeness, or, perhaps because of it, the image seemed to be suitable for the funerary context. It is thus tempting to think that it was understood by the deceased, or by someone who placed the vessel next to the grave, as an allusion to something thought of as "Orphic".

\section{BIBLIOGRAPHY}

A. BERNABÉ, "El mito órfico de Dioniso y los Titanes," in A. BERNABÉ, F. CASADESÚs (eds.), Orfeo y la tradición órfica. Un reencuentro, Madrid, 2008, p. 591-607.

R. BLOCH, Recherches sur les religions de l'antiquité classique, Genève, 1980.

C.O. BRINK, Horace on Poetry. Vol. II: The 'Ars Poetica', Cambridge, 1971.

F. BROMMER, Vasenlisten zur griechische Heldensage, Marburg, 1973.

W. BURKERT, “Greek Tragedy and Sacrificial Ritual,” GRBS 7.2 (1966), p. 87-121.

-, Homo necans. Interpretationen altgriechischer Opferriten und Mythen, Berlin, 1972.

T.H. CARPENTER, Dionysian Imagery in Fifth-Century Athens, Oxford, 1997.

K. DEICHGRÄBER, “Die Lykurgie des Aischylos,” Nach. Gött. 1.3 (1939), p. 231-309.

M. DETIENNE, Dionysos mis à mort, Paris, 1977.

-, "Culinary Practices and the Spirit of Sacrifice," in M. DETIENNE, J.-P. VERnANT (eds.), The Cuisine of Sacrifice among the Greeks, Chicago/London, 1989, p. 1-20.

M. DI MARCo, "Dioniso ed Orfeo nelle Bassaridi di Eschilo," in A. MASARACCHIA (ed.), Orfeo e l'orfismo. Atti del Seminario Nazionale (Roma-Perugia 1985-91), Roma 1993, p. 101-153.

R.G. EDMONDS III, "Tearing Apart the Zagreus Myth: A Few Disparaging Remarks on Orphism and Original Sin," ClAnt 18.1 (1999), p. 35-75.

-, Redefining Ancient Orphism: A Study in Greek Religion, Cambridge, 2013.

G. EKROTH, "Meat in Ancient Greece. Sacrificial, Sacred or Secular?," Food and History 5.1 (2007), p. 249-272.

C. FARAONE, "Gender Differentiation and Role Models in the Worship of Dionysus: The Thracian and Thessalian Pattern," in A. BERNABÉ, A.I. JIMÉNEZ, M. HERRERO, R. MARTíN (eds.), Redefining Dionysus, Berlin, 2013, p. 120-143.

D. FERRIN SUTTON, “Aeschylus' Edonians," in Fons Perennis. Saggi critici di Filologia Classica raccolti in onore del prof. Vittorio D’Agostino,Torino, 1971, p. 387-411.

-, "A Series of Vases Illustrating the Madness of Lycurgus," RSC 23 (1975), p. 351-355.

H.P. FOLEY, Ritual Irony: Poetry and Sacrifice in Euripides, Ithaca/London, 1985.

E. FRAENKEL, Aeschylus. Agamemnon, Oxford, 1950. 
D. GORZELANY, “Oblicza dionizyjskie. Kilka uwag o ikonografii Dionizosa i Ariadny na wazach greckich w zbiorach Fundacji KsiĄżąt Czartoryskich i Muzeum Narodowego w Krakowie," Rozprawy Muzeum Narodowego w Krakowie 4 (2011), p. 35-48.

J. GOULD, “Hiketeia,” JHS 93 (1973), p. 74-103.

F. GRAF, Eleusis und die orphische Dichtung Athens in vorhellenistischer Zeit, Berlin/New York, 1974.

-, "One generation after Burkert and Girard: where are the great theories?" in C.A. FARAONE, F.S. NAIDEN (eds.), Greek and Roman Sacrifice: Ancient Victims, Modern Observers, Cambridge, 2012, p. 32-51.

D. GRAHAM, The Texts of Early Greek Philosophy: The Complete Fragments and Selected Testimonies of the Major Presocratics, Cambridge, 2010.

J.R. GREEN, “Dedications of masks,” RA 2 (1982), p. 237-248.

W.K.C. GUTHRIE, Orpheus and Greek Religion: A Study of the Orphic Movement, London, 1935.

G. HAUPT, Commentationes archaeologicae in Aeschylum, Halle, 1896.

A. HENRICHS, “Greek Maenadism from Olympias to Messalina,” HSCP 82 (1978), p. 121-160.

-, "Drama and Dromena: Bloodshed, Violence, and Sacrificial Metaphor in Euripides," HSCP 100 (2000), p. 173-188.

-, "Animal Sacrifice in Greek Tragedy: Ritual, Metaphor, Problematizations," in C.A. FARAONE, F.S. NAIDEN (eds.), Greek and Roman Sacrifice: Ancient Victims, Modern Observers, Cambridge, 2012, p. $180-194$.

G. HERMANN, “De Aeschyli Lycurgia dissertatio,” in ID., Opuscula, vol. 5, Leipzig, 1834, p. 3-30.

A. HEUBECK, S. WEST, J.B. HAINSWORTH, A Commentary on Homer's Odyssey. Vol. I, Oxford, 1988.

H. JEANMAIRE, Dionysos. Histoire du culte de Bacchus, Paris, 1951.

F. JOUAN, “Dionysos chez Eschyle," Kernos 5 (1992), p. 71-86.

E. KEFALIDOU, "The Iconography of Madness in Attic Vase-Painting," in J.H. OAKLEY, O. PALAGIA (eds.), Athenian Potters and Painters 2, Oxford, 2009, p. 90-99.

A. LAMARI, "Visual Intertextuality in Ancient Greek Drama: Euripides' Bacchae and the use of the Art Media," in A. KAMPAKOGLOU, A. NOVOKHATKO (eds.), Gaze, Vision, and Visuality in Ancient Greek Literature, Berlin/Boston, 2018, p. 187-204.

L. LATTANZI, “Il Lycurgus di Nevio,” Aevum Antiqum 7 (1994), p. 191-265.

I.M. LINFORTH, “Two Notes on the Legend of Orpheus," TAPhA 62 (1931), p. 5-17.

-, The Arts of Orpheus, Berkeley/Los Angeles, 1941.

R. MAYHEW, Prodicus the Sophist: Texts, Translations, and Commentary, Oxford, 2011.

H. METZGER, Les répresentations dans la céramique attique du IV siècle, Paris, 1951.

F. MOLINA, "La música de Orfeo," in A. BERNABÉ, F. CASADESÚs (eds.), Orfeo y la tradición órfica. Un reencuentro, Madrid, 2008, p. 33-58.

F.S. NAIDEN, Ancient Supplication, Oxford, 2006.

-, Smoke Signals for the Gods: Ancient Greek Sacrifice from the Archaic through Roman Periods, Oxford, 2013. 
H. ORANJE, Euripides' Bacchae: The Play and its Audience, Leiden, 1984.

B.M. PALUMBo, “Eschilo, fr. 23 N²," RFIC 94 (1966), p. 407-413.

R. PARKER, Miasma: Pollution and Purification in Early Greek Religion, Oxford, 1983.

-, On Greek Religion, Ithaca/London, 2011.

M. PEDRINA, “Tendre les mains, toucher du regard : Télèphe et Dryas, ” in L. BODIOU, D. FRÈRE, V. MEHL (eds.), L'expression des corps. Gestes, attitudes, regards dans l'iconographie antique, Rennes, 2006, p. 299-310.

-, La supplication sur les vases grecs. Mythes et images, Pisa/Roma, 2017.

L. PIOTROWICZ, "De Lycurgo insano in hydria Cracoviensi repraesentato," in Stromata in Honorem Casimiri Morawski, Kraków, 1908, p. 79-87.

W. RAECK, Zum Barbarenbild in der Kunst Athens im 6. und 5. Jahrhundert v. Chr., Bonn, 1981.

N. RUDD, Horace. Epistles Book II and Epistle to the Pisones ('Ars poetica'), Cambridge, 1989.

K. SCHEFOLD, Die Göttersage in der klassischen und hellenistischen Kunst, München, 1981.

F.L. SCHUDDEBOOM, Greek Religious Terminology - Telete \& Orgia, Leiden/Boston, 2009.

R. SEAFORD, “Homeric and Tragic Sacrifice", TAPhA 119 (1989), p. 87-95.

-, Euripides: Bacchae, Warminster, 1996.

L. SÉCHAN, Études sur la tragédie grecque dans ses rapports avec la céramique, Paris, 1926.

C. SMITH, “Orphic Myths on Attic Vases," JHS 11 (1890), p. 343-351.

F. SPALTENSTEIN, Commentaire des fragments dramatiques de Naevius, Bruxelles, 2014.

K. TOPPER, "Dionysus Comes to Thrace: The Metaphor of Corrupted Sacrifice and the Introduction of Dionysian Cult in Images of Lykourgos's Madness," Arethusa 48.2 (2015), p. 139-167.

L. TRZCIONKOWSKI, “Orfeusz na orchestrze teatru ateńskiego. Kilka uwag o Bassaridach Ajschylosa," in K. NARECKI (ed.), Starożytny dramat. Teoria. Praktyka. Redepcja, Lublin, 2011, p. 47-68.

D. TSIAFAKIS, "The Allure and Repulsion of Thracians in the Art of Classical Athens," in B. COHEN (ed.), Not the Classical Ideal: Athens and the Construction of the Other in Greek Art, Leiden, 2000, p. 364389.

F. VAN STRATEN, “Ancient Greek animal sacrifice: gift, ritual slaughter, communion, food supply, or what? Some thoughts on simple explanations of a complex ritual," in S. GEORGOUDI, R. KOCH PIETTRE, F. SCHMIDT (eds.), La Cuisine et l'Autel. Les sacrifices en questions dans les sociétés de la Méditerranée ancienne,Turnhout, 2005, p. 15-29.

S.B. WATSON, “Mousikê and Mysteries: A Nietzschean Reading of Aeschylus' Bassarides," CQ 65.2 (2015), p. 455-475.

F.G. WELCKER, Nachtrag zu der Schrift über die Aeschylische Trilogie, nebst einer Abhandlung über das Satyrspiel, Frankfurt, 1826.

M.L. WEST, Studies in Aeschylus, Stuttgart, 1990.

U. VON WILAMOWITZ-MOELLENDORFF, Der Glaube der Hellenen, Berlin, 1931-2.

F.I. ZEITLIN, “The Motif of the Corrupted Sacrifice in Aeschylus' Oresteia," TAPhA 96 (1965), p. 463508. 


\section{NOTES}

1. British Museum E 246; BAD 9981; LIMC Dionysos 796 = Lykourgos I 15. The vase was found at a tomb in Rhodes, but its Athenian provenance seems to be out of the question. It has been dated in various ways; SMITH (1890), p. 343 (followed by JEANMAIRE [1951], p. 407)) thought it was produced in the fourth century BCE, but more recent scholars (thus: GREEN [1982], p. 242; LIMC Lykourgos I 15, Dionysus 796; SCHEFOLD [1981], p. 87; TSIAFAKIS [2000], p. 382; TOPPER [2015], p. 151) tend to date it around $450 \mathrm{BCE}$ or slightly earlier.

2. GREEN (1982), p. 242 observes that this detail may be evocative of a mask and, as such, of the theatrical origins of the scene.

3. SMITH (1890), p. 345.

4. Thus also GUTHRIE (1935), p. 130-133; JEANMAIRE (1951), p. 407-408; SCHEFOLD (1981), p. 87; BAP (1981).

5. WILAMOWITZ (1931-2), II, p. 193; EDMONDS (1999) and (2013), p. 296-391; for the opposite view, see especially BERNABÉ (2008).

6. TOPPER (2015), p. 152.

7. The gesture of Dionysus has been variously interpreted in the past. SMITH (1890), p. 344 describes it as an expression of surprise; GUTHRIE (1935), p. 130 writes: "I cannot feel any doubt that Dionysos by his look and gesture expresses dismay and protest"; JEANMAIRE (1951), p. 407: "réprobation"; BLOCH (1980), pl. xii: "réprobation ou consentement?"; KEFALIDOU (2009), p.95: "Dionysus is totally agreeable to what is taking place".

8. Thus also: RAECK (1981), p. 88; GREEN (1982), p. 242; TSIAFAKIS (2000), p. 381-382; KEFALIDOU (2009), p. 95; BROMMER (1973), p. 503; METZGER (1951), p. 263, n. 3. In LIMC (Lykourgos I 15) the image figures among dubious representations of Lycurgus.

9. A thorough discussion of the sources on Lycurgus myth will be provided in my forthcoming book.

10. TGF $1.7 \mathrm{~T}$. The only piece of information we have is that this tetralogy won the third prize in the competition at the City Dionysia.

11. On the Lycurgeia as one of the late tetralogies of Aeschylus, see WEST (1990), p. 48-50. Its popularity can be deduced from the fact that Aristophanes parodied it almost a half century later in his Thesmophoriazousae (134-145). The reconstruction of the entire tetralogy or parts thereof has been attempted by many scholars, most notably: WELCKER (1826), p. 103-122; HERMANN (1834); HAUPT (1896), p. 137-160; SÉCHAN (1926), p. 63-79; DEICHGRÄBER (1939); FERRIN SUTTON (1971); WEST (1990); JOUAN (1992), p. 72-76; DI MARCO (1993); TRZCIONKOWSKI (2011); WATSON (2015).

12. Apollod. 3.5.1.

13. Kraków, National Museum 1225; ARV ${ }^{2}$ 1121.17; Beazley Addenda ${ }^{2} 331$; BAD 214835; LIMC Lykourgos I 26. See LAMARI (2018), p. 191-192; TOPPER (2015); GORZELANY (2011), p. 35-36; CARPENTER (1997), p. 37; PIOTROWICZ (1908).

14. In Homer (Il. 6.135), Lycurgus wields a bouplex, a typically sacrificial weapon; an Apulian crater in London (LIMC Lykourgos I 28 = Lyssa 8) features a capsized hydria next to an altar, an Apulian amphora in Naples (LIMC Lykourgos I 20) - a leg of an animal. These and similar clues strongly suggest that Lycurgus was about to perform a sacrifice when something happened - he saw Dionysian thiasos, went mad or perhaps both (see FARAONE [2013], p. 126). Nonnus (D. 20.149181) describes Lycurgus as a notoriously impious individual, who used to sacrifice strangers to Ares and expected his subjects to sacrifice to himself. See SÉCHAN (1926), p.75; FERRIN SUTTON (1975).

15. For the identification of the scene under discussion as that of supplication, see NAIDEN (2006), p. 44-62, 273 n. 299; PEDRINA (2006), p. 305-307 and (2017), p. 26, 255.

16. E.g. Il. 14.495-498. 
17. PEDRINA (2017), p. 29-49 et passim.

18. The term introduced by HENRICHS (2012).

19. The most notorious example of such a violation is provided by the abduction of Cassandra by Ajax (cf. Od. 1.325-7 with a commentary of HEUBECK - WEST - HAINSWORTH [1988], ad loc.; Il. Pers.; Alc. 298 Voigt).

20. E.g. Her. 6.91.

21. PARKER (1983), p. 146, 180-188; GOULD (1973), especially p. 77-78, 97; NAIDEN's (2006), p. 8-18 survey of the secondary literature is useful but offers a slightly exaggerated view of his predecessors' reductionism.

22. As an anonymous reviewer of this paper observed, cannibalism violates one of the most fundamental taboos. As PARKER (1983), p. 305 put it, "cannibalism was, for Greeks, one of those extreme pollutions, often imagined, though never experienced - like parricide, or incest with the mother - which served to define by contrast the proper human condition". Thus, in terms proposed by DETIENNE (1977), p. 136, it is bon à penser, as it provides a clear anti-model for interpersonal relations that by any standards can be taken as acceptable. Admittedly, that this pathology occurred in Lycurgus' family, especially in a tragic form of the story, is not impossible. However, neither is it automatically true that Lycurgus ate his son.

23. TOPPER (2015) reproduces a fine example in fig. 3 (= LIMC Kassandra I 202).

24. E.g. LIMC Medeia 29, 30, 36.

25. There seem to be two strands of research on animal sacrifice in tragedy. What may be called a positivist approach was represented by BURKERT (especially 1966 and 1972), who used tragedy as one of the most important sources in his reconstruction of the meaning and origins of the Greek animal sacrifice. Accordingly, Burkert emphasised the violence underlying acts of sacrificial killing. His theory has been justly criticised in recent years, notably for the overconfident use of sources; see for example GRAF (2012); HENRICHS (2012), p. 181-182. The other strand, represented most notably by ZEITLIN (1965), followed by HENRICHS (2000) and (2012) and FOLEY (1985), concentrates on the sacrificial imagery of Greek tragedy as a means of expression. Even though not all of the statements made by Zeitlin and her followers are immune to criticism, it seems that such an approach generally defends itself (as often happens with theories of a seemingly lesser heuristic potential).

26. SEAFORD (1989). It may be added that whereas epic places more emphasis on communal aspect of feasting, comedy stresses its hedonistic dimension, which leads comic heroes to asocial or even antisocial behaviour.

27. A. Ag. 150.

28. A. Ag. 1219-1222.

29. Among the most important developments recently made in the research of Greek animal sacrifice is the rejection of the previous assumption of "the absolute coincidence of meat-eating and sacrificial practice", as DETIENNE (1989), p. 3 called it. Within such a model, virtually all meat that was consumed was supposed to come from sacrifices and be eaten in sanctuaries. Thus, a close conceptual link between meat consumption and sacrifices seemed natural (see e.g. FRAENKEL [1950], ad 1592 with further references). This does not seem tenable in light of zoo-archaeological discoveries (showing that the relationship between animals killed at altars and meat consumed in sanctuaries was rather loose) and the data regarding meat markets, where sacrificial and nonsacrificial meat was sold. Combined, these factors suggest that, unlike some Aristophanic characters obsessed with consumption, Greeks did not necessarily always associate sacrifice with eating. For this reason, the link between human sacrifice and cannibalism is far from obvious. On the subject-matter see, among others: NAIDEN (2013), especially p. 230-275; PARKER (2011), p. 124170; EKROTH (2007); VAN STRATEN (2005). 
30. As an anonymous reviewer observed, Dryas is actually being killed on an altar, not next to it, as a sacrificial victim would be. If ancient viewers were sensitive to this detail (which we cannot know with certainty), it could have been enough to assure them that the scene in question had little to do with sacrifice.

31. Nonn. D. 20.149-21.169.

32. Nonn. D. 21.117-123 (ed. KEYDELL [1959]).

33. All translations from Greek and Latin are mine.

34. Ar. R.1032 (ed. DOVER [1993]).

35. For the translation of $\tau \varepsilon \lambda \varepsilon \tau \alpha i ́$ as "rites" in this particular context, see sCHUDDEBоoм (2009), p. 19-20 with further references.

36. See references in GRAF (1974), p. 34, n. 64.

37. SOMMERSTEIN (1996), ad loc.; DOVER (1993), ad loc.

38. GRAF (1974), p. 34-36. See also GUTHRIE (1935), p. 40-41; LINFORTH (1941), p. 67-71; 255-257.

39. Them. Or. 30 (349a).

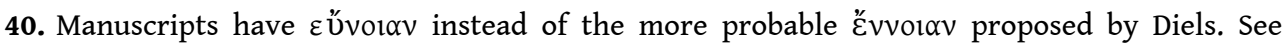
MAYHEW (2011), ad loc.

41. Them. Or. 30 (350b-c, ed. SCHENKL 1971).

42. DIELS-KRANTZ; GRAHAM (2010); MAYHEW (2011).

43. Hor. AP 391-3 (ed. BRINK 1971).

44. For such an allegorical interpretation, see MOLINA (2008), p. 42-45.

45. On uictus foedus as cannibalism: BRINK (1971), ad loc. with further references; RUDD (1989), p. ad loc.

46. WEST (1990), p. 33-36; DI MARCO (1993), p. 116-124.

47. The story of Orpheus as a digression: SÉCHAN (1926), p.68-69; LINFORTH (1931), p. 11-17; PALUMBO (1966), p. 410, n. 2. Convincing arguments against: DI MARCO (1993), p. 124-127.

48. Virtually all scholars claim that the story of Orpheus was told in the Bassarai, the second play of the tetralogy. In my opinion, however, it should be attributed to the Neaniskoi, the last tragedy. Given that this problem is marginal to the subject-matter of the present article and that it requires quite an extensive discussion of the sources (which I intend to present elsewhere), I believe that for the time being it will suffice to observe that such a solution is possible because the only testimony, the Catasterism 24, says that Orpheus was killed by the Bassarids/Bassarai and

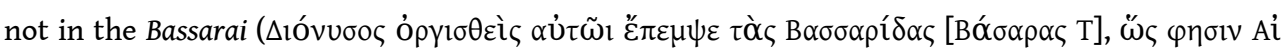

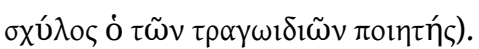

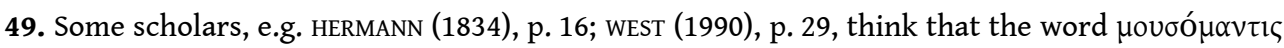
in fr. 60 Radt of the Edonoi referred to Orpheus. This would mean that the singer had already appeared on stage in the first part of the tetralogy, which is not impossible; however, the only other text that brings Orpheus and Lycurgus together, a passage in Diodorus of Sicily (3.65.4-6), speaks of the singer as being a grandson of certain Charops, the man who replaced Lycurgus on the throne of Thrace. Quite obviously, Diodorus' euhemeristic version of mythical events cannot be taken at face value as a summary of any poetic variant of the story; however (as I argue in my forthcoming book), in spite of all distortion, it is likely to reflect some traditional motifs. Thus, it is probable (although uncertain) that Orpheus was a much younger contemporary of Lycurgus. If

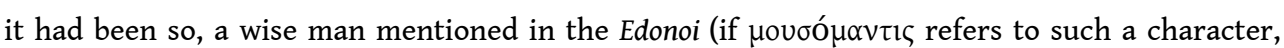
which is far from certain) could be his grandfather or his father.

50. Interestingly, in a fragment of Naevius' Lycurgus (Schauer 30) the destruction of crops is mentioned: ... quaque incedunt, omnis aruas opterunt. We do not know who is said to tread the fields (although it is natural to think of the Dionysian thiasos, see LATTANZI [1994], ad loc.; SPALTENSTEIN [2014], ad loc.), but the fragment clearly presupposes that, at least in this version, agriculture had already been known in Thrace before the advent of Dionysus. 
51. In spite of some (at least at first glance) attractive analogies between omophagia, as mentioned in line 139 of the Bacchae, sparagmos of Pentheus, and the events of the Lycurgeia reconstructed here, the fact that these similarities can be misleading needs particular emphasis, given first, that omophagia (which seems to refer to a kind of raw offering to the god rather than to the practice of worshippers eating raw meat) belongs to the sphere of the cult rather than to myth (see esp. HENRICHS [1978], p. 150-152), and second, that sparagmos of Pentheus had no outwardly cannibalistic purpose. Within the structure of the play, it corresponds quite neatly to the death of Lycurgus' son and of Orpheus, as a combination of both these deaths dramatized in the Lycurgeia. On the other hand, the mythical reversal of the norms of an already "civilized" society triggered by the advent of Dionysus (which is parallel to the cannibalistic frenzy in the Lycurgeia) finds its climax in the Bacchae, in the first messenger speech (esp. 734-764), in which maenads are plundering Boeotian villages. Of particular import is the sparagmos of oxen and the abduction of

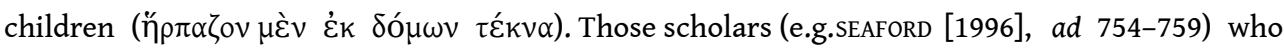
think that the description reflects the cult practice, are rejecting the idea that the children were killed and eaten by maenads. The text, however, does not contain any information regarding the purpose of the abduction. If the audience had been familiar with a similar story (told in the Lycurgeia) in which children were kidnapped for cannibalistic purposes, this is probably how they would understand the reference in the Bacchae. See ORANJE (1984), p. 181-186.

52. For a detailed reconstruction of the Lycurgeia, see my forthcoming book.

53. The setting, although without much detail, is described by SMITH (1890), p. 343.

\section{ABSTRACTS}

The man in a Thracian outfit represented on a hydria in London as eating a dead child has been interpreted either as a Titan with Zagreus or Lycurgus with his son. Neither of these interpretations seems plausible, especially in light of our present knowledge about sacrificial rules. As I argue, the image is more likely to be inspired by a story dramatized in the Lycurgeia of Aeschylus, in which an advent of Dionysus to the country ruled by Lycurgus caused an epidemic of cannibalism. With much likelihood, this motif was also present in a passage - unfortunately only partially preserved - in Nonnus' Dionysiaca (21.117-123). This mythical crisis was subsequently solved by Orpheus, which seems clear from passages in Aristophanes, Horace and Themistius, who allude to a rationalized version of this story.

Sur une hydrie conservée à Londres, un homme en vêtement thrace en train de manger un enfant mort a été interprété comme l'image d'un Titan avec Zagreus, ou comme celle de Lycurgue dévorant son fils. Aucune de ces interprétations n'emporte l'adhésion, notamment en regard de notre connaissance des processus sacrificiels. L'image est plutôt inspirée par une intrigue mise en scène par Eschyle dans la Lycurgeia, où l'arrivée de Dionysos dans le pays dirigé par Lycurgue avait suscité une épidémie de cannibalisme. Selon toute vraisemblance, ce motif était aussi conservé dans un passage des Dionysiaques de Nonnos (XXI, 117-123), malheureusement fragmentaire. Cette crise mythique était ensuite résolue par Orphée, ainsi que l'attestent Aristophane, Horace et Thémistius, qui font référence à une version rationalisée de cette histoire. 
AUTHOR

BARTEK BEDNAREK

Faculty of History, University of Warsaw

bp.bednarek@uw.edu.pl 